\title{
The Pronominal Element in Arabic Copular Clauses
}

\author{
Bader Alharbi ${ }^{1}$ \\ ${ }^{1}$ Department of English Language and Translation, Qassim University, Saudi Arabia \\ Correspondence: Bader Alharbi, Department of English Language and Translation, Qassim University, Saudi \\ Arabia. E-mail: byhrby@qu.edu.sa
}

Received: February 2, 2020

Accepted: April 1, 2020

Online Published: April 12, 2020

doi:10.5539/ijel.v10n4p21

URL: https://doi.org/10.5539/ijel.v10n4p21

\begin{abstract}
In Arabic, a pronominal element (PE) (Note 1) appears in almost all copular clause types, specifically the specificational, identificational, and identity clauses, as well as in clauses with a post-copular definite description. It is obligatory in an identity clause consisting of proper nouns and is otherwise optional. However, the PE cannot be used in Arabic predicational clauses. This paper examines the nature of this PE, why it is illicit in the predicational clause and licit in all other types, and why it is obligatory only in the identity clause consisting of proper nouns and is otherwise optional. It suggests that the PE is a realization of the F head (the identity predicate) in the structure of the identity clause. The illicit use of the PE in the predicational clause follows from the presence of predicative expressions in this type of clause. Lastly, it is shown that the PE is obligatory only in an identity clause involving proper nouns to avoid ambiguity, and is otherwise optional.
\end{abstract}

Keywords: pronominal element, PRON, pronominal copula, Arabic, copular clause

\section{Introduction}

In Arabic (Note 2), or more specifically Standard Arabic (SA), a PE appears in nearly all copular clause types, including specificational, identificational, and identity clauses, as well as in clauses with a post-copular definite description, as exemplified in (1) and (2). It is obligatory only in identity clauses consisting of proper nouns and is otherwise optional.

(1) Michel Chalhoub

Michel Chalhoub

\section{*(huwa)}

he

\section{Omar-u}

Omar-NOM

$$
\begin{aligned}
& \check{s} \text {-šariif } \\
& \text { the-šariif }
\end{aligned}
$$

$$
\text { [Identity Clause] }
$$
(2) Pal-malik-u
(huwa)
the-king-NOM
he
Zayd-un
Zayd-NOM

'The king is Zayd.'

[Specificational Clause]

In contrast, the PE can never be used in a predicational clause in Arabic, as shown in (3).
(3) Zayd-un
(*huwa) taalib-un
Zayd-NOM
he
student.Masc.Sg-NOM
'Zayd is a student.'

The PE in Arabic copular clauses has received various analyses in the literature. It has been analyzed as a copular morpheme similar to the Arabic copular verb $K W N$ (Li \& Thompson, 1977), an identity pronoun occurring in the copular verb position (Eid, 1991), an auxiliary like the copula $K W N$ base-generated in the Pred head and raised to T (Ouhalla, 2013), and a linker marking the syntactic relation between subject and predicate DPs (Choueiri, 2016). All of these analyses have faced a number of theoretical and empirical challenges. In this paper, I provide a new different account for the PE in Arabic copular clauses. In particular, I explain the nature of this PE, including why it is illicit in the predicational clause and licit in all other types, and why it is obligatory only in the identity clause consisting of two proper nouns and is otherwise optional.

The current proposal departs from previous analyses in two major ways. Specifically, this proposal examines the $\mathrm{PE}$ in all Arabic copular clause types and it does not associate the PE with the copula $K W N$. I suggest that Arabic copular clause types can be classified into two types: the predicational clause and the identity clause. In this 
view, the specificational clause, the identificational clause, and the clause with a post-copular definite description are all considered subtypes of the identity clause. The two clause types differ in the type of small clause (SC) they contain, with a PredP in the predicational clause and a functional phrase (FP) in the identity clause, as in (4). I go on to show that the PE that appears in nearly all Arabic copular clauses, with the exception of the predicational clause, is a realization of the $\mathrm{F}$ head in the structure of the identity clause.

(4) a. [PredP DP subject $_{\text {[Pred }}$ Pred $\left.\left.\varnothing \mathrm{NP} / \mathrm{AP} / \mathrm{PP}\right]\right]$

$$
\text { b. [FP DP [F' }[\mathbf{P E}] \quad \mathrm{DP}]]
$$

The paper is structured as follows: Section (2) reviews the major work that has already been done on the PE in Arabic. Section (3) presents an overview of Arabic copular clause types. Section (4) discusses the use of the PE in all Arabic copular clauses. Section (5) provides my analysis of the PE. Section (6) concludes the paper.

\section{Previous Analyses}

Researchers to date have provided a variety of analyses for the PE in Arabic copular clauses. Li and Thompson (1977) first analyzed the PE in Palestinian Arabic (PA) as a copular morpheme, similar to the copular verb. It functions as a link between the two NPs involved in an equational sentence. Their analysis implied that the PE, which is a copula in their view, does not cooccur with the Arabic copular verb $K W N$. However in SA as illustrated in (5), and in other Arabic dialects such as Najdi Arabic (NA), it is possible to have both the copular verb $K W N$ and the PE in one clause. If we assume that the PE in (5) is a copular morpheme as they suggest, then it is not clear how we will account for the copular verb $K W N$ in the same clause. Is it possible to claim that a single simple clause can have multiple copulas?

\section{$\begin{array}{llll}\text { (5) kaan-at l-bint-u (hiya) l-mudarris-at-a } & \end{array}$ \\ be.PST-3.Fem.Sg the-girl-NOM she the-teacher-Fem.Sg-ACC}

'The girl was the teacher.'

Later, Eid (1991) analyzed the PE in Egyptian Arabic (EA) equative sentences as an identity pronoun that expresses an identity relation between two arguments. Structurally it occurs in the position of the copular verb $K W N$, as demonstrated in (6), but it is not a verb. Rather, it heads the NP argument located in the predicate position. It assigns its theme-role to its sister NP, and the whole predicate NP assigns a $\theta$-role to the subject.

(6) [IP [NP Subject] I [AGR] [nP PE [nP Predicate]]]

Eid pointed out that obligatory agreement in gender and number between the PE and the NP occurs within the predicate NP, and the features of the PE are checked through agreement with its sister NP.

Eid did not present a detailed account of the use of the PE in all Arabic copular clause types, such as in identificational and specificational clauses. However, this is necessary in order to attain a more plausible analysis of the PE in Arabic. Additionally, Eid claimed that in EA the PE and the copula $K W N$ are in complementary distribution and cannot cooccur in the same sentence as in (7). According to her, the PE occurs only in present tense sentences, while the copula $K W N$ occurs only in past and future tense sentences.

$$
\begin{array}{rrlll}
\text { (7) * } \text { Cali } & \text { kaan } & \text { huwwa } & \text { zariif } & \\
\text { Ali } & \text { was } & \text { he } & \text { nice } & \text { (Eid, 1991, p. 34) }
\end{array}
$$

This claim is not supported by SA and other Arabic dialects. As mentioned previously, the PE can cooccur with the copular verb $K W N$, as illustrated in (8) from SA and (9) from NA. The example that Eid provided in (7) is

\begin{tabular}{|c|c|c|c|}
\hline $\begin{array}{l}\text { (8) a. } \text { kaan-a } \\
\text { be.PST-3.Masc.Sg } \\
\text { 'The winner was Zayd }\end{array}$ & $\begin{array}{l}\text { l-faariz-u } \\
\text { the-winner-NOM } \\
\text { d.' }\end{array}$ & $\begin{array}{l}\text { (huwa) } \\
\text { he }\end{array}$ & $\begin{array}{l}\text { Zayd-an } \\
\text { Zayd-ACC }\end{array}$ \\
\hline $\begin{array}{l}\text { b. } \text { kaan-a } \\
\text { be.PST-3.Masc.Sg } \\
\text { 'Zayd was the king.' }\end{array}$ & $\begin{array}{l}\text { Zayd-un } \\
\text { Zayd-NOM }\end{array}$ & $\begin{array}{l}\text { (huwa) } \\
\text { he }\end{array}$ & $\begin{array}{l}\text { l-malik-a } \\
\text { the-king-ACC }\end{array}$ \\
\hline $\begin{array}{rll}\text { )) Pahmad } & \text { wa Khalid } \\
\text { Ahmad } & \text { and Khalic }\end{array}$ & $\begin{array}{ll}d & \boldsymbol{k a a n}-\boldsymbol{u} \boldsymbol{u} \\
\text { id } & \text { be.PST-3.Mas }\end{array}$ & $\begin{array}{l}\text { (hum) } \\
\text {.Pl they }\end{array}$ & $\begin{array}{l}\text { l-mudarrisiin } \\
\text { the-teachers }\end{array}$ \\
\hline
\end{tabular}
ungrammatical because the PE cannot be used in Arabic predicational clauses, not because of its cooccurrence with the copula $K W N$. 
'Ahmad and Khalid are the teachers.'

In addition, Ouhalla (2013) analyzed the PE, as in (10), as an auxiliary similar to the copula $K W N$. As demonstrated in (11), the PE is base-generated in the Pred head and then raised to T. It differs from the copula $K W N$ in that it lacks the ability to value case features on post-copular expressions.
(10) Zaynab-u
(hiyya)
jamiil-at-un
Zaynab-NOM
(3.Fem.Sg)
pretty-Fem.Sg-NOM.Indef
'Zaynab is pretty.'
(11) [тр T[Agr] [PredP PRON [dp D[Indef, uCase] [fp F[Agr] [Adjp [dp Zaynab] [Adj jamiilat ... (Oualla, 2013, pp. 321-323)

Based on the example in (10), Ouhalla seems to assume that the PE can be used in Arabic predicational clauses. Unlike Ouhalla, in this paper, I argue that the PE cannot be used in the Arabic predicational clause at all. A question therefore arises as to the nature of this pronoun as it occurs in (10). I assume that the pronoun in this example is not the same PE that occurs in other Arabic copular clauses, but is instead just a regular pronominal subject (i.e., the subject of a predicate). Note that the DP Zaynab is a topic that is base-generated in the left-dislocated position, such as Spec-TP or Spec-CP (see Soltan, 2007). Furthermore, there appears to be a short pause after the pronunciation of the left-dislocated DP. These facts support the idea that the PE cannot be used in Arabic predicational clauses. Finally, Ouhalla's claim that the copula $K W N$ is used in Arabic past tense sentences and the PE is used in Arabic present tense sentences implies that both the copula and the PE cannot cooccur in a single sentence. Indeed, his analysis suggests that they are both auxiliaries. However, the cooccurrence of the copula and the PE in Arabic copular clauses is possible on empirical grounds.

Most recently, Choueiri (2016) suggested that the equational sentence whose predicate is a definite NP (i.e., a name, a pronoun, a demonstrative NP, or a definite description) has a more complex structure than the predicational sentence whose predicate is an NP, AP, or PP. The structure of the equational sentence involves an extra FP located between TP and PredP, as in (12), whereas the structure of the predicational sentence does not. The PE projects in the head F that functions as an independent head and a linker marking the syntactic (thematic) relation between the subject and predicate DPs. The impossibility of a PE in the predicational clause follows from the absence of this FP in its structure.

(12) [тр T [KWN] [Fp F [PE] [Predp DP subject [Pred' Pred DP]]]]

Choueiri assumes that the head F, which bears the features [3 Per, Num and Gen] (Note 3), always agrees with the subject of the predication (i.e., the DP in the Spec-PredP). That is, the PE seems to be the phonological exponent of the features in $\mathrm{F}$.

Choueiri's account faces some challenges. First, she did not examine the use of the PE in all Arabic copular clause types. This may be because she did not distinguish the various clause types and instead treated them all as equational sentences. She also did not discuss the optionality of the PE in all Arabic copular clause types. Second, if the projection of the FP marks the syntactic relation between the two DPs in an equational sentence, why do we need to project PredP (SC)? The majority of the literature assumes that PredP mediates the predicational (syntactic) relation between a subject and a predicate (cf. Bowers, 1993; Mikkelsen, 2005; among others). Lastly, Choueiri ascribed the impossibility of a PE in predicational clauses to the absence of an FP in the structure of the predicational clauses. However, it is not obvious what bars the FP from projecting in predicational clauses involving non-verbal predicates (NPs, APs, and PPs) and thus a PredP.

This section has examined the major work that has already been done on the PE in Arabic copular clauses. Researchers have provided different analyses for this PE, viewing it as a copular morpheme, an identity pronoun, an auxiliary, and a linker. All of these analyses encounter both theoretical and empirical issues. The analysis I will provide in this paper departs from these works in two respects, namely: I examine the PE in all Arabic copular clause types and I do not associate the PE with the copular verb $K W N$.

\section{Arabic Copular Clause Types}

In this section I present a concise description of the various copular clause types in Arabic using Higgins's (1979) taxonomy as well as a number of influential works by several other linguists. Beginning with the most commonly discussed copular clause type, the predicational clause is a clause that tells us something about the subject. To clarify, the predicational clause contains a nonverbal predicate, either an NP, AP, or PP, which resembles a verbal predicate in that it predicates a certain property about the subject. Consider, for instance, the copular clauses in (13). In (13.a) the NP muSallim 'teacher' denotes Zayd's job and in (13.b) the AP saYiid 
'happy' denotes the state of the boy at a certain moment in the past.
(13) a. kaan-a
Zayd-un
muSallim-an
be.PST-3.Masc.Sg
Zayd-NOM
teacher.Masc.Sg-ACC
'Zayd was a teacher.'
b. kaan-a
l-walad-u
sasiid-an
be.PST-3.Masc.Sg the-boy-NOM
happy.Masc.Sg-ACC
'The boy was happy.

Next is the specificational clause, a clause that informs, or specifies, who or what a referent is. The first NP in this clause is analogous to the head of a list, with the second NP functioning as an item or entry on that list (Higgins, 1979). Consider, for example, the copular clauses in (14) where (14.a) specifies who the king is, (14.b) specifies who the teacher is, and (14.c) specifies who the winner is. It can be noted that in each of these examples the second element may be a proper noun, pronoun or definite NP, whereas the first element is always a definite NP.
(14) a. Pal-malik-u
Zayd-un
the-king-NOM
Zayd-NOM
'The king is Zayd.'
b. Pal-muYallim-u Panta/Panaa
the-teacher-NOM you/I
'The teacher is you/me.'
c. Pal-faa?iz-u l-muSallim-u
the-winner-NOM the-teacher-NOM
'The winner is the teacher.'

In the literature, there is a great deal of debate on the status of this type of copular clause. As a result, two different analyses of the specificational clause have been put forward. Some linguists analyze it as an inverse predicational clause (Bondaruk, 2013; Heggie, 1988; Mikkelsen, 2005; Moro, 1997), whereas others analyze it as an identity clause (Hedberg \& Potter, 2010; Heycock \& Kroch, 1998, 1999; Rothstein, 2004). In Section (5), I show that the Arabic specificational clause favors the latter analysis.

The third type of copular clause, the identity clause (also known as the equative clause), is a clause that expresses an identity relation between two expressions. As pointed out by Higgins (1979), the identity clause is typically composed of two definite NPs, two proper NPs, two pronouns, or an amalgamation of these items, as illustrated in (15). Each of these examples signals an identity relation between two referential DPs. That is, the two DPs in each clause both denote the same individual, hence the reason these clauses are called identity clauses.

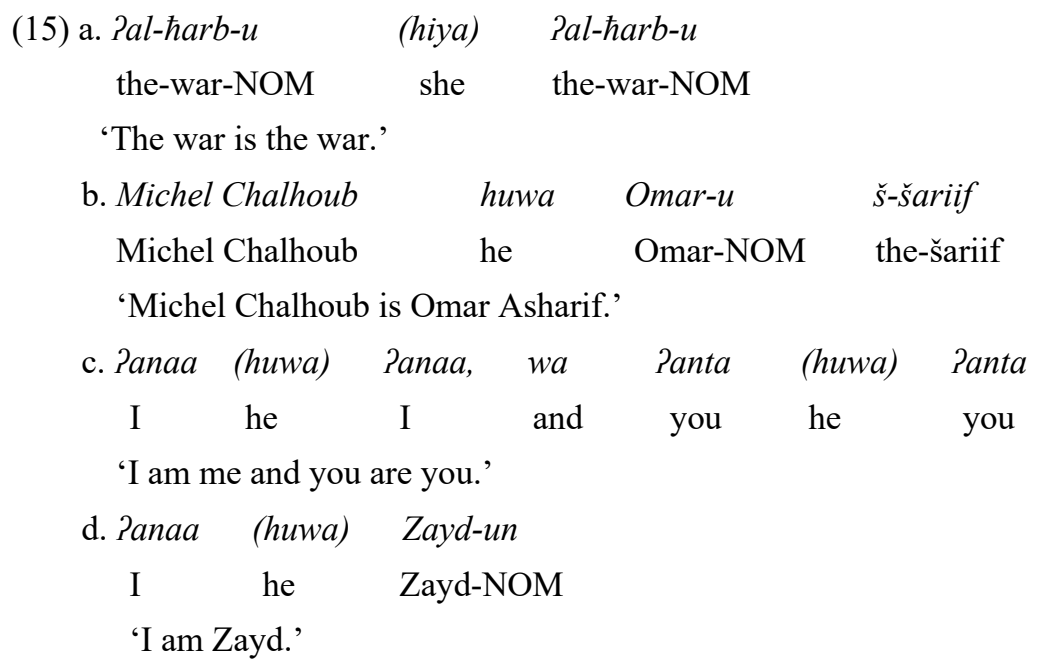

Next is the identificational clause, a clause that tells (identifies) the name of a person or thing (Higgins, 1979). It 
typically consists of demonstrative and nominal expressions, as shown in (16). In (16.a), the identificational clause tells who "this girl" is, and in (16.b) it tells who "that man" is.

$\begin{array}{cll}\text { (16) a. haaðihi } & \text { l-bint-u } & \text { Hind-un } \\ \text { this } & \text { the-girl-NOM } & \text { Hind-NOM }\end{array}$

'This girl is Hind.'

$\begin{array}{clc}\begin{array}{c}\text { b. Jaalika } \\ \text { that }\end{array} & \text { r-radzul-u } & \text { Zayd-un } \\ & \text { the-man-NOM } & \text { Zayd-NOM }\end{array}$

'That man is Zayd.'

Unlike the preceding types, the identificational clause has received little attention in the literature. Most linguists simply treat this type as an identity clause (cf. Hedberg \& Potter, 2010; Heggie, 1988; Higgins, 1979; Mikkelsen, 2005). Higgins explicitly states that the identificational clause can be analyzed as an identity clause if one takes referentiality as a property of expressions themselves rather than a function of their usage. In Section (5), I show that this type of copular clause is indeed a subtype of an identity clause.

The last Arabic copular clause type is the copular clause with a definite description (i.e., a post-copular definite $\mathrm{NP})$, as in (17).

(17) Pahmad-u l-muSallim-u

Pahmad-NOM the-teacher-NOM

'Ahmad is the teacher.'

It is not obvious whether the clause in this example is better classified as a predicational or identity clause. Some people consider it a predicational clause, where the NP lmuSallim predicates a property of the subject NP Pahmad (Heggie, 1988; Mikkelsen, 2005; Moro, 1997), whereas others prefer to classify it as an identity clause, where the NP ImuSallim denotes the same individual Pahmad (Carnie, 1995, 1997; Roy, 2013). Still others consider this clause ambiguous (Higginbotham, 1987; Higgins, 1979; Rothstein, 2004). In Section (5), I assume that this clause is a subtype of the identity clause.

This section has broadly defined and described the various copular clause types found in Arabic; these are the predicational, specificational, identity, and identification clause types. I have also briefly mentioned a special type of Arabic copular clause, one with a definite description in the post-copular position.

\section{The Use of the PE}

In this section, I present a detailed account of the use of the PE in the various Arabic copular clauses discussed in the preceding section. The PE, which is identical to a third-person nominative pronoun in Arabic, obeys different constraints across the different Arabic copular clause types. It can be used in the specificational clause (18), the identificational clause (19), and the identity clause (20). It can even be used in a copular clause containing a post-copular definite NP as shown in (21).

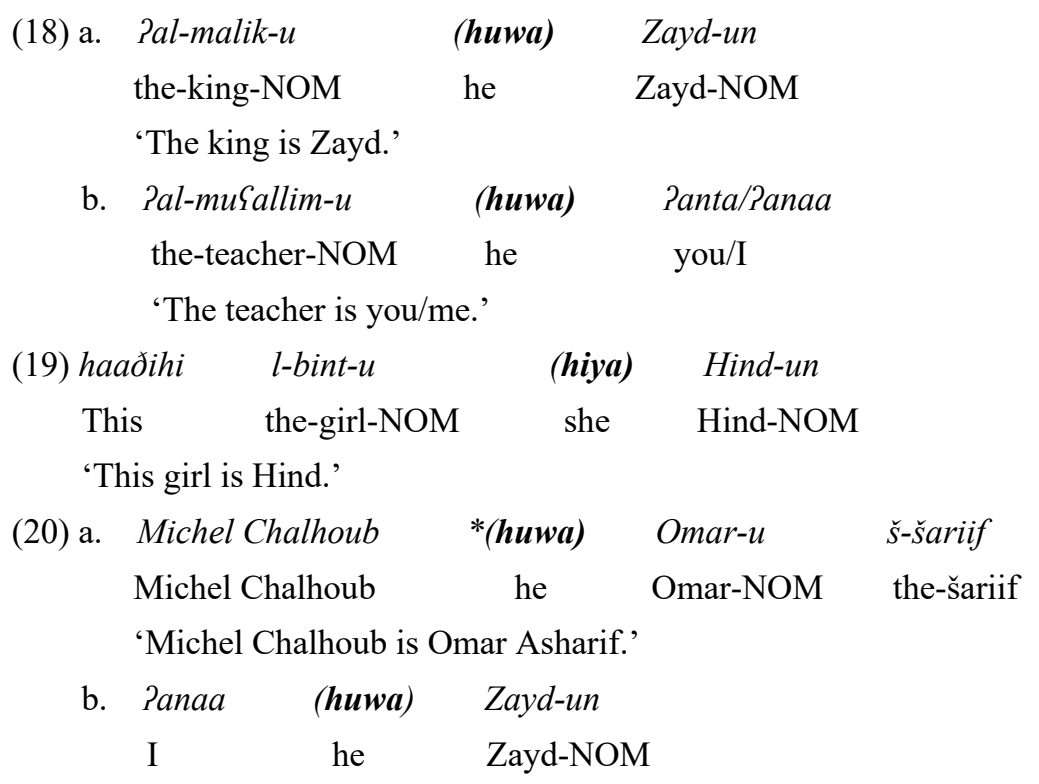




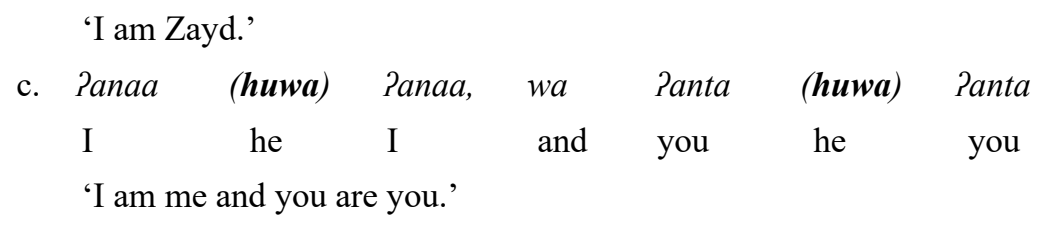
(21) Zayd-un (huwa) l-malik-u
Zayd-NOM he the-king-NOM
'Zayd is the king.'

Two observations need to be made regarding the above data. First, the PE is obligatory only in an identity clause consisting of proper nouns as in (20.a), but is otherwise always optional. Second, the PE can only be found with clauses that allow a definite NP, a proper NP, a pronoun, or a demonstrative NP in the pre-copular and post-copular positions.

In contrast, a PE cannot be used in an Arabic predicational clause as shown in (22), where the predicates are an $\mathrm{NP}$ in (22.a), an AP in (22.b), and a PP in (22.c).

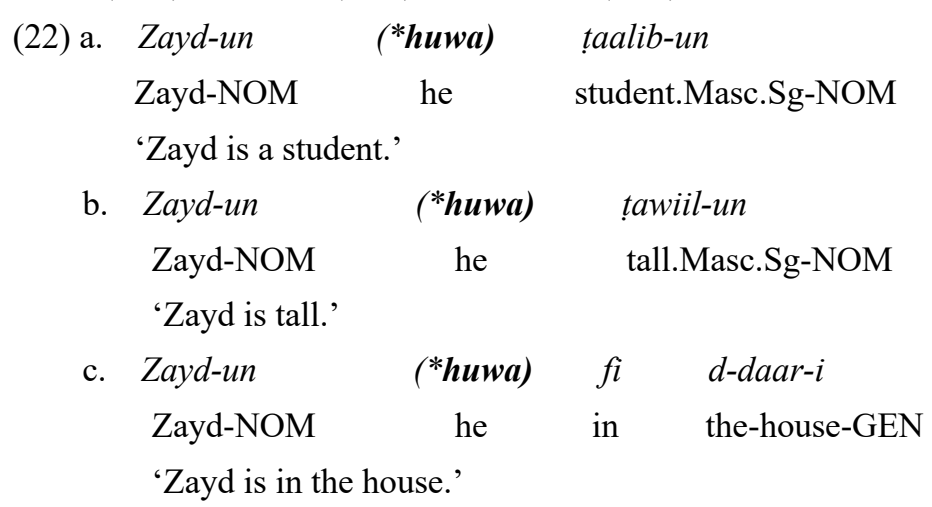

Thus, the PE can be found in nearly all copular clause types, including specificational, identificational, and identity clause types, as well as in a clause with a post-copular definite description. It is obligatory only in identity clauses consisting of proper nouns and is otherwise optional. However, it cannot be used in a predicational clause in Arabic.

As shown in all above examples, the PE must occur between the two DPs. It cannot be positioned sentence-initially or sentence-finally, as illustrated in (23).
(23) a. *huwa (Note 4)
he
l-malik-u
the-king-NOM
'The king is Zayd.'

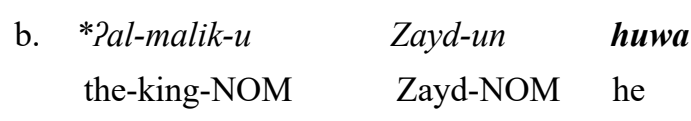
'The king is Zayd.'

Zayd-un

Zayd-NOM

Before proceeding to the analysis section, one should note that Arabic is not the only language that uses a PE in its copular clauses; there are other languages that use an extra pronoun in their copular clauses as well. For instance, Rothstein (2004) points out that in Hebrew the PE (Note 5) is optional in the predicational clause as in (24.a), but obligatory in the identity clause as in (24.b).

(24) a. dani (hu) rofe

dani m.sg doctor

'Dani is a doctor,'

$\begin{array}{cccc}\text { b. dani } & *(h u) & \text { mar } & \text { yosef } \\ \text { dani } & \text { m.sg. } & \mathrm{mr} & \text { yosef }\end{array}$

'Dani is Mr Yosef.' $\quad$ (Rothstein, 2004, pp. 206-207)

Furthermore, Roy (2013) reports that in the Russian identity clause, specifically in the present tense, two DPs are 
separated by the deictic pronoun eto 'this/that' as shown in (25.a), whereas in the predicational clause the predicate appears immediately after the subject as shown in (25.b).

(25) a. Utrennaja zvezda *(eto) večernaja zvezda.

[morning star].NOM eto [evening star].NOM

'The morning star is the evening star.'

b. Puškin velikij poèt.

Pushkin [great poet].NOM

'Pushkin is a great poet.' (Roy, 2013, p. 138)

Finally, the agreement morpheme in Irish is optional in the predicational clause (26.a) but obligatory in the identity clause (26.b) (Carnie, 1995, 1997).
(26) a. Is dochtúir (i) Máire
COMP doctor (AGR) Mary
'Mary is a doctor.'
$\begin{array}{lllll}\text { b. Is } & i & \text { Máire an captaen } \\ \text { COMP AGR } & \text { Mary the captain }\end{array}$
'Mary is the captain.' (Carnie, 1997, p. 62)

\section{PE: A Realization of the Identity Predicate (F Head)}

Before presenting the analysis, I shall briefly state the assumptions on which it is based. First, the specificational clause is a subtype of the identity clause. Both of the two expressions it contains have the same syntactic category (DP) and the same semantic type $(<\mathrm{e}>)$, which is to say that they are both referential (cf. Hedberg \& Potter, 2010; Heller, 2005; Heycock \& Kroch, 1998, 1999; Rothstein, 2004). Second, the identificational clause should be classified as an identity clause, as both of its DPs are referential (of type $<\mathrm{e}>$ ) (cf. Hedberg \& Potter, 2010; Heggie, 1988; Higgins, 1979; Mikkelsen, 2005). Last, the copular clause with a post-copular definite description is an identity clause, since its definite description is referential (Carnie, 1995, 1997; Roy, 2013).

\section{Two Copular Clauses in Arabic: Predicational and Identity Clauses}

In the light of the above assumptions, I suggest that Arabic copular clauses can be classified into two well-defined types: the predicational clause as in (13.a) repeated here as (27) and the identity clause as in (20.a) repeated here as (28).

(27) kaan-a

be.PST-3.Masc.Sg

$$
\text { Zayd-un }
$$

muSallim-an

'Zayd was a teacher.'

(28) Michel Chalhoub

Zayd-NOM

teacher.Masc.Sg-ACC

Michel Chalhoub

$$
\text { *(huwa) }
$$

Omar-u

š-šariif

'Michel Chalhoub is Omar Asharif.'

Omar-NOM

the-šariif

I assume, following Heycock and Kroch $(1998,1999)$, Carnie $(1995,1997)$ and Rothstein (2004), that these two clauses differ in the type of small clause (SC) they contain. The SC in a predicational clause is a PredP, as demonstrated in (29), (see Baker, 2008; Bondaruk, 2013; Bowers, 1993; Mikkelsen, 2005; Roy, 2013). The Pred head, which is morphologically null, mediates the predicational relation between the nonverbal predicate (NP, $\mathrm{AP}$, or PP) of type $<\mathrm{e}, \mathrm{t}>$ and its subject DP, which is of type $<\mathrm{e}>$. It takes the nonverbal predicate as its complement and the subject DP as its specifier. That is, the predicational relation takes place within the SC (PredP).

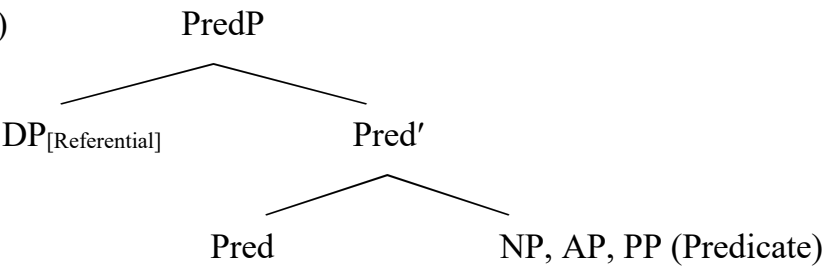


On the other hand, the SC in an identity clause is a FP, as demonstrated in (30), (cf. Carnie, 1995, 1997; Hedberg \& Potter, 2010; Heycock \& Kroch, 1998, 1999; Reeve, 2010). Both of the two DPs in the identity clause are referential (of type $<\mathrm{e}>$ ), and thus none of them is a predicate of the other. The identity (or equative) relation is associated with the $\mathrm{F}$ head, the identity predicate. The $\mathrm{F}$ head denotes $\lambda \mathrm{y} \lambda \mathrm{x}[\mathrm{x}=\mathrm{y}]$, or more particularly "identical with", (see Hedberg \& Potter, 2010; Higginbotham, 1987; Roy, 2013 for the equative copula in English). This FP in the structure of the identity clause is similar to the COPP or the Equative Phrase (EqP) proposed by Carnie $(1995,1997)$ and Reeve (2010) respectively.

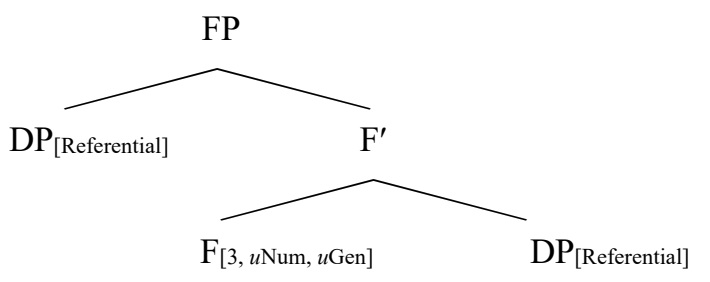

PE

The two different SCs, FP and PredP, are selected by $v \mathrm{P}$, which hosts the copula $K W N$ in Arabic, or directly by TP in Arabic verbless sentences as demonstrated in (31). I assume, following Heycock and Kroch $(1998,1999)$, Heggie (1988), Mikkelsen (2005), and many others, that the copula $K W N$ in all Arabic copular clauses is semantically vacuous, as it does not participate in predicational or identity relations. As we have just seen, predicational and identity relations are obtained within the $\mathrm{SC}$ without the presence of the copula $K W N$. That is why I suggest that it should project outside the SCs, specifically in the $v \mathrm{P}$.

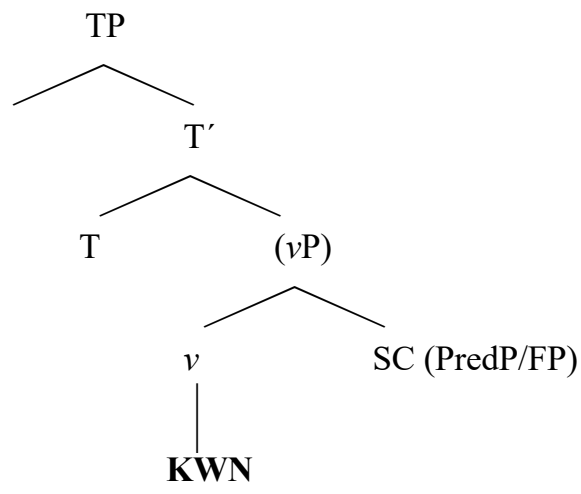

As for the specificational clause in (32.a), the identificational clause in (32.b), and the copular clause with a post-copular definite description in (32.c), I consider these clauses as subtypes of the identity clause because they express an identity relation (see Hedberg \& Potter, 2010; Heller, 2005; Heycock \& Kroch, 1998, 1999; Rothstein, 2004 for the specificational clause, Hedberg \& Potter, 2010; Heggie, 1988; Higgins, 1979; Mikkelsen, 2005 for the identificational clause, and Carnie, 1995, 1997; Roy, 2013 for the copular clause with a post-copular definite description).

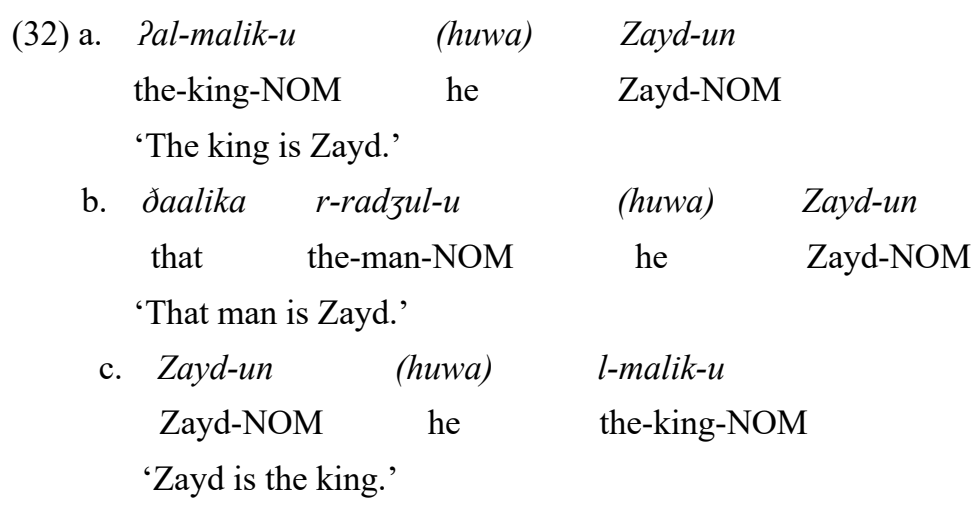

There are two reasons motivating this proposal. First, the DPs in each of these clauses are referential (of type $<\mathrm{e}>$ ). Both DPs refer to the same individual, which is the main characteristic of the identity clause. Second, certain tests (Note 6), including VP ellipsis (VPE) and inversion, indicate that these clauses behave similarly to the identity clause (cf. Bondaruk, 2013; Heller \& Wolter, 2008; Higgins, 1979; Mikkelsen, 2005; Rothstein, 
2004; Roy, 2013). As an illustration, the VPE (Note 7) can target the predicate complement in the Arabic predicational clause as shown in (33), but it cannot target the predicate complement in all other types of Arabic copular clauses, specifically the specificational clause in (34.a), the identity clause in (34.b), the identificational clause in (34.c), and the copular clause with a post-copular definite description in (34.d). Following Rothstein and Mikkelsen, I assume that the VPE is allowed in the Arabic predicational clause because the predicate complement in this clause type is predicative (property-denoting). However, it is not allowed in all other types of Arabic copular clauses because in these clause types the predicate complement is referential (individual-denoting).

(33) kaan-a

$$
\text { Zayd-un muðiis-an }
$$

be.PST-3.Masc.Sg

$\begin{array}{llll}\text { wa } & \text { kaan- } a & \text { Fahad-un } & \text { kaðaalik } \\ \text { and } & \text { be.PST-3.Masc.Sg } & \text { Fahad-NOM } & \text { too }\end{array}$

'Zayd was an announcer and Fahad was too.'

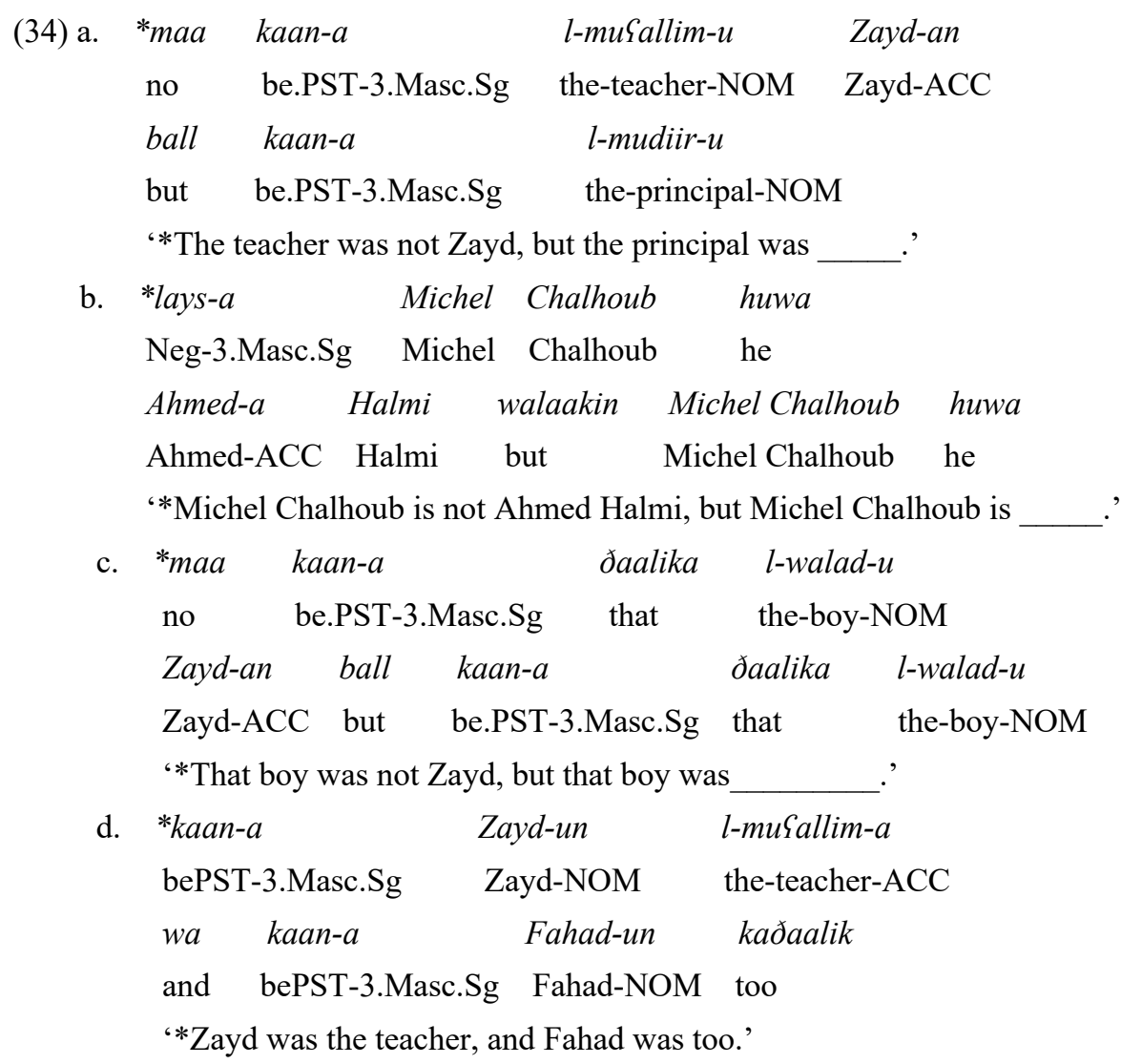

In addition, inversion of the two NPs is allowed in all Arabic copular clauses, as illustrated in (35), (36) and (37), but it is not allowed in the Arabic predicational clause, as shown in (38).

(35) Specificational Clause
a. kaan- $a$
Fahad-un
l-faa?iz- $a$
be.PST-3.Masc.Sg Fahad-NOM
the-winner-ACC

'Fahad was the winner.'
b. kaan-a
l-faa?iz-u
Fahad-an
be.PST-3.Masc.Sg
the-winner-NOM
Fahad-ACC

'The winner was Fahad.'

(36) Identificational Clause
a. haaðihi
l-madiin-at-u
(hiya)
London 
this the-city-Fem.Sg-NOM she London

'This city is London.'

$\begin{array}{llll}\text { b. London } & \text { (hiya) } & \text { haadihi } & \text { l-madiin-at- } u \\ \text { London } & \text { she } & \text { this } & \text { the-city-Fem.Sg-NOM }\end{array}$

'London is this city.'

(37) Identity Clause
a. Michel Chalhoub
huwa
Omar-u
$\check{S}$-šariif
Michel Chalhoub
he Omar-NOM
the-šariif

'Michel Chalhoub is Omar Asharif.'
b. Omar-u š-šariif huwa Michel Chalhoub
Omar-NOM the-šariif he Michel Chalhoub

'Omar Asharif is Michel Chalhoub.'

(38) Predicational Clause
a. kaan-a
be.PST-3.Masc.Sg
'Zayd was a teacher.'
Zayd-un
muSallim-an
Zayd-NOM
teacher.Masc.Sg-ACC
b. \#kaan-a
be.PST-3.Masc.Sg
muSallim-an
teacher.Masc.Sg-ACC
Zayd-un (Note 8)
'*A teacher was Zayd.'
Zayd-NOM

Consequently, I suggest that these three clauses have the same SC in (30), which is provided for the identity clause. Following Hedberg and Potter (2010), as well as Bondaruk (2013) for the English identity clause, I assume that these three clause types and the identity clause type differ in the order in which the two DPs have been merged. That is, either DP can project in Spec-FP or as a complement of F. This is supported by the fact that all Arabic copular clauses, excluding the predicational clause, allow inversion of the two DPs.

\section{PE: A Realization of the F Head}

In English, and perhaps other languages as well, the F head in the structure of the identity clause is always empty (see Hedberg \& Potter, 2010; Heycock \& Kroch, 1998, 1999). However, in Arabic I suggest that the PE, for example huwa 'he' in (28) and (32), which occurs in all Arabic copular clause types but the predicational type, is a realization of the F head, the identity predicate. I adopt Baker's (2008) theory of agreement (Note 9) which claims that the $\mathrm{F}$ head in the structure of nonverbal predicates can probe upward for an XP to agree with on the condition that XP c-commands F. I then assume that the F head in the structure of the identity clause, with the features [3, $u \mathrm{Num}, u \mathrm{Gen}]$, enters Agree with the DP in its specifier, as demonstrated in (39).

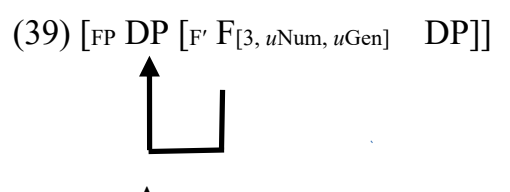

Agree

This agreement results in the valuation of gender and number features of the F head. Note that the F head here is specified for third-person as the PE that occurs in Arabic copular clauses always bears a third person-feature (Note 10). This is in line with Carnie's $(1995,1997)$ assumption that the obligatory agreement morpheme in the Irish identity clause is a realization of the null identity head COP. However, this proposal suggests that it is not the case that the PE agrees with the post-copular DP as proposed by Eid (1991). Examples in (40) illustrate that the PE in Arabic always agrees with the preceding DP, and not with the following DP.
(40) a. Panaa
huwa/*hiya
l-muškil-at-u
I (Masc.Sg)
he/*she
the-problem-Fem.Sg-NOM
'I am the problem.'
b. Pal-muškil-at-u 
the-problem-Fem.Sg-NOM ??he/she I (Masc.Sg)

'The problem is me.'

The cooccurrence of the copula $K W N$, which I assume to be in a $v$ P (see Aoun et al., 2010; Benmamoun, 2000), and the PE in a single clause, as shown in (8.b) and repeated here as (41), presents additional evidence that the $\mathrm{PE}$ is located within the SC, particularly in the F head.

\section{(41) kaan-a}

be.PST-3.Masc.Sg

'Zayd was the king.'

\section{Zayd-un \\ (huwa)}

Zayd-NOM he

\section{l-malik-a}

the-king-ACC

Furthermore, I suggest that the illicit use of the PE in the predicational clause follows from the presence of predicative expressions (NP, AP, or PP), which are of type $<\mathrm{e}, \mathrm{t}>$, in this type of copular clause. These expressions directly predicate properties of their subjects. Consequently, the PE in Arabic copular clauses can be taken as empirical evidence supporting the presence of the FP in the structure of the identity clause and for its absence in the structure of the predicational clause (see also Heycock \& Kroch, 1998, 1999; Reeve, 2010). This proposal is different from Choueiri's (2016) analysis, which suggests that the predicational and equational clauses have the same SC, namely the PredP, but differ in that the equational clause projects an extra FP above the SC to host the PE. On the other hand, this proposal is close to Rothstein's (2004) analysis for the PRON in Hebrew copular clauses, although not identical. Rothstein analyzes the PRON in Hebrew copular clauses as a realization of agreement features in Infl. She argues that the PRON is optional in the Hebrew predicational clause because the predicate can be directly predicated of the subject, but it is obligatory in the Hebrew identity clause because this clause does not contain a predicate.

As for the optionality and obligatoriness of the PE, I argue that whenever it is used in Arabic copular clause types the PE is almost always optional. It is obligatory only in an identity clause consisting of proper nouns, as in (20.a) repeated here as (42) and as in (43) to avoid ambiguity. Without the presence of the PE, the proper nouns in (42) and (43) could be interpreted as a single constituent (i.e., it looks as if a speaker lists names of certain people). To put it differently, the proper nouns may be interpreted as a phrase as opposed to a clause. This assumption is close, though not identical, to Eid's (1991) assumption that the PE is always obligatory in EA equational sentences in order to force a sentential interpretation, rather than a phrasal interpretation.

(42) Michel Chalhoub

\section{*(huwa)}

he

Omar-u

Omar-NOM

$$
\check{s} \text {-šariif }
$$

Michel Chalhoub

'Michel Chalhoub is Omar Asharif.'

\section{(43) Pahmad-u}

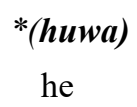

Zayd-un

Pahmad-NOM

he

Zayd-NOM

'Ahmad is Zayd.'

In $\mathrm{SA}$, proper nouns differ in morphological case in the presence of the copula $K W N$, as illustrated in (44) where Pahmad bears a nominative case and Zayd bears an accusative case. In this example, the use of the PE becomes optional, as there is no possibility of interpreting the two proper nouns as a single constituent. That is, the morphology here serves to remove the ambiguity.

\begin{tabular}{|c|c|c|c|}
\hline (44) $f i$ & l-masrahiyy-at-i & kaan-a & Pahmad-u \\
\hline in & the-play-Fem.Sg-GEN & be.PST-3.Masc.Sg & Pahmad-NOM \\
\hline (huwa) & Zayd-an & & \\
\hline he & Zayd-ACC & & \\
\hline
\end{tabular}

'In the play, Ahmad was Zayd.'

Additionally, sometimes morphological case does not show up on certain proper nouns, such as Yahya and Eisaa, for purely morphological reasons in Arabic. In this case, the use of the PE becomes obligatory even in the presence of the copula $K W N$, as shown in (45), as there is a possibility of interpreting the two proper nouns as a phrase rather than a clause.

$\begin{array}{clc}\text { (45) } f i \quad l \text {-masrahiyy-at- } i & \text { kaan-a } & \text { Yahya } \\ \text { in the-play-Fem.Sg-GEN } & \text { be.PST-3.Masc.Sg } & \text { Yahya } \\ \text { *(huwa) Eisaa } & & \end{array}$


he Eisaa

'In the play, Yahya was Eisaa.'

Therefore, it can be concluded that the use of the PE is nearly always optional in Arabic copular clause types. It is obligatory only in the identity clause consisting of proper nouns, specifically when they do not differ in morphological case markers, in order to explain ambiguity. Without the PE, proper nouns could be interpreted as a phrase rather than a clause.

\section{Conclusion}

In this paper, I suggest that Arabic copular clause types can be reduced to two types: the predicational clause and the identity clause. The two clauses differ in the type of SC selected by $v \mathrm{P}$ or directly by TP in Arabic verbless sentences. These SCs are a PredP for the predicational clause and a FP for the identity clause. The specificational clause, the identificational clause, and the clause with a post-copular definite description are all subsumed under the identity clause, as they each express an identity relation. They have the same SC as is suggested for the identity clause. Further, I propose that the PE, which appears in all Arabic copular clause types except the predicational clause, is a realization of the $\mathrm{F}$ head (the identity predicate). The illicit use of the PE in the predicational clause is attributed to the presence of predicative expressions in this type of clause. Finally, it is shown that the PE is obligatory only in an identity clause involving proper nouns in order to avoid ambiguity, and is otherwise optional.

\section{References}

Alharbi, B. (2017). The syntax of copular clauses in Arabic. Doctoral dissertation, University of Wisconsin, Milwaukee.

Aoun, J., Benmamoun, E., \& Choueiri, L. (2010). The syntax of Arabic. New York: Cambridge University Press. https://doi.org/10.1017/CBO9780511691775

Baker, M. (2008). The syntax of agreement and concord. New York: Oxford University Press. https://doi.org/10.1017/CBO9780511619830

Benmamoun, E. (2000). The feature structure of functional categories: A comparative study of Arabic dialects. New York: Oxford University Press.

Bondaruk, A. (2013). Copular clauses in English and Polish. Structure, derivation and interpretation. Lublin: Wydawnictwo KUL.

Bowers, J. (1993). The syntax of predication. Linguistic Inquiry, 24, 591-656.

Carnie, A. (1995). Non-Verbal predication and head movement. Doctoral dissertation. MIT, Cambridge.

Carnie, A. (1997). Two types of non-verbal predication in modern Irish. Canadian Journal of Linguistics, 42, 57-73. https://doi.org/10.1017/S0008413100016820

Choueiri, L. (2016). The pronominal copula in Arabic. Brill's Journal of Afroasiatic Languages and Linguistics, 8, 101-135. https://doi.org/10.1163/18776930-00801005

Eid, M. (1991). Verbless sentence in Arabic and Hebrew. In B. Comrie \& M. Eid (Eds.), Perspectives on Arabic linguistics (pp. 31-61). Amsterdam: John Benjamins. https://doi.org/10.1075/cilt.80.05eid

Fassi, F. A. (1993). Issues in the structure of Arabic clauses and words. Dordrecht: Kluwer. https://doi.org/10.1007/978-94-017-1986-5

Hedberg, N., \& Potter, D. (2010). Equative and predicational copulas in Thai. Annual Meeting of the Berkeley Linguistics Society, 36(1), 144-157. https://doi.org/10.3765/bls.v36i1.3908

Heggie, L. (1988). The syntax of copular structures. Doctoral dissertation. Retrieved form ProQuest (UMI No. DP29067).

Heycock, C., \& Kroch, A. (1998). Inversion and equation in copular sentences. In A. Alexaidou, N. Fuhrhop, U. Keinhenz \& P. Law (Eds.), ZAS paper in Linguistics (pp. 71-87). Berlin: Zentrum Für Allgemeine Sprachwissenschaft.

Heycock, C., \& Kroch, A. (1999). Pseudocleft connectedness: Implications for the LF interface level. Linguistic Inquriy, 30, 365-397. https://doi.org/10.1162/002438999554110

Higginbotham, J. (1987). Indefiniteness and predication. In E. Reuland \& A. ter Meulen (Eds.), The representation of (In)definiteness (pp. 43-70). Cambridge: MIT Press. 
Higgins, F. (1979). The pseudo-cleft construction in English. New York: Garland.

Li, C., \& Thompson, S. (1977). A mechanism for the development of copula morphemes. In C. Li (Ed.), Mechanisms of syntactic change (pp. 419-444). Austin \& London: University of Texas Press.

Mikkelsen, L. (2005). Copular clauses. Specificational, predicational and equation. Amsterdam: John Benjamins. https://doi.org/10.1075/la.85

Mohammad, M. (2000). Word order, Agreement and pronominalization in Standard and Palestinian Arabic. Philadelphia: John Benjamins. https://doi.org/10.1075/cilt.181

Moro, A. (1997). The raising of predicates:Predicative noun phrases and the theory of clause structure. New York: Cambridge University Press. https://doi.org/10.1017/CBO9780511519956

Ouhalla, J. (2013). Agreement unified Arabic. In L. Cheng \& N. Corver (Eds.), Diagnosing syntax (pp. 314-333). Oxford: Oxford University Press. https://doi.org/10.1093/acprof:oso/9780199602490.003.0015

Reeve, M. (2010). Clefts. Doctoral dissertation, University College London, London.

Rothstein, S. (2004). Predicates and their subjects. Kluwer: Dordrecht. https://doi.org/10.1007/978-94-010-0690-3

Roy, I. (2013). Nonverbal predication:Copular sentences at the syntax-semantics interface. Oxford: Oxford University Press. https://doi.org/10.1093/acprof:oso/9780199543540.001.0001

Soltan, U. (2007). On formal feature licensing in Minimalism: Aspects of Standard Arabic morphosyntax. Doctoral dissertation, University of Maryland, College Park.

\section{Notes}

Note 1. In traditional Arabic grammar, the PE is known as a pronoun of separation, whereas it is known as a pronominal copula PRON in the literature of generative grammar. In this paper, I use the term PE as the nature of this kind of pronoun is not yet clear.

Note 2. Throughout the paper "Arabic" and Standard Arabic "SA" will be used interchangeably, while the other dialects will be referred to by their abbreviated names.

Note 3. Per $=$ Person, Num $=$ Number, and Gen $=$ Gender .

Note 4. Notice that this sentence can be grammatical in SA, but the pronoun here is not the PE that I investigate in this paper. It is called ḍamiir Pašša?an, which can be interpreted as a cleft or focus marker.

Note 5. Rothstein uses the term PRON, not PE, in her work on Hebrew copular clauses.

Note 6. VP ellipsis (VPE) and inversion are only two of several tests indicating that these clauses behave similarly to the identity clause.

Note 7. Rothstein (2004) refers to this process as "Predicate Ellipsis".

Note 8. Notice that this sentence is grammatical in Arabic under the assumption that the predicate NP muYalliman 'teacher' is fronted or topicalized.

Note 9. Baker (2008) provides a unified theory of agreement, which is a modified version of Chomsky's (2000, 2001) Theory of Agree.

Note 10. Fassi-Fehri (1993) and Mohammad (2000) point out that in MSA the pronoun of separation, which is a $\mathrm{PE}$ in this paper, agrees with the first DP in gender and number but not in person.

\section{Copyrights}

Copyright for this article is retained by the author, with first publication rights granted to the journal.

This is an open-access article distributed under the terms and conditions of the Creative Commons Attribution license (http://creativecommons.org/licenses/by/4.0/). 